University of Nebraska - Lincoln

DigitalCommons@University of Nebraska - Lincoln

Biological Systems Engineering: Papers and

Publications

Biological Systems Engineering

$7-2010$

\title{
Securing Foreign Oil: A Case for Including Military Operations in the Climate Change Impact of Fuels
}

Adam J. Liska

University of Nebraska-Lincoln, aliska2@unl.edu

Richard K. Perrin

University of Nebraska-Lincoln, rperrin@unl.edu

Follow this and additional works at: https://digitalcommons.unl.edu/biosysengfacpub

Part of the Biological Engineering Commons

Liska, Adam J. and Perrin, Richard K., "Securing Foreign Oil: A Case for Including Military Operations in the Climate Change Impact of Fuels" (2010). Biological Systems Engineering: Papers and Publications. 176. https://digitalcommons.unl.edu/biosysengfacpub/176

This Article is brought to you for free and open access by the Biological Systems Engineering at DigitalCommons@University of Nebraska - Lincoln. It has been accepted for inclusion in Biological Systems Engineering: Papers and Publications by an authorized administrator of DigitalCommons@University of Nebraska Lincoln. 


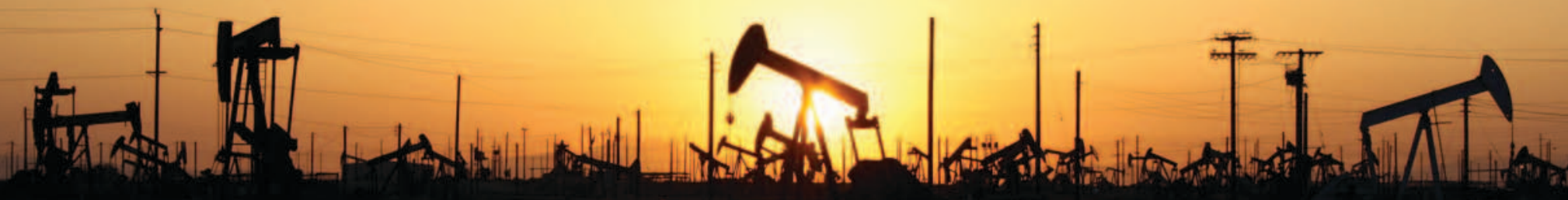

\title{
Securing Foreign Oil:
}

\section{A Case for Including Military Operations in the Climate Change Impact of Fuels}

\author{
by Adam J. Liska and Richard K. Perrin
}

$\mathrm{M}$ ilitary operations are major industrial activities that use massive amounts of fuel and materials that significantly contribute to climate change. In this article, we assert that military activity to protect international oil trade is a direct production component for importing foreign oil - as necessary for imports as are pipelines and supertankers-and therefore the greenhouse gas (GHG) emissions from that military activity are relevant to U.S. fuel policies related to climate change. Military security for protection of global maritime petroleum distribution is part of the acquisition process, but in addition, recent Middle Eastern wars may also be related to securing petroleum reserves.

A component of U.S. motor fuel policy has been to encourage the development of biofuels as substitutes for petroleum, both to reduce de- pendence on foreign oil and to reduce GHG emissions. To qualify for this substitution under the U.S. Energy Independence and Security Act of 2007 (EISA), specific biofuel types must reduce GHG emissions by set amounts from 20 to 60 percent compared with gasoline. The EISA legislation demands evaluation of not only direct life cycle emissions from biofuels, but also all potentially significant indirect emissions. Yet the 
gasoline emissions against which this is compared consist only of direct life cycle emissions, which to this point have not included emissions due to the military component of transporting foreign oil to the United States. These military emissions are analyzed here to determine their contribution to the life cycle GHG emissions from gasoline production. This analysis builds on a recent estimate that emissions from military security raised the GHG intensity of U.S. gasoline derived from Middle Eastern imports by twofold compared with direct emissions. ${ }^{1}$

Direct GHG emissions from the production of biofuels are becoming better understood after years of scientific controversy. ${ }^{2}$ Unfortunately, the process of setting regulatory GHG emissions standards for fuels is complicated by poorly understood indirect GHG emissions that result from the production of both biofuels and gasoline. ${ }^{3} \mathrm{~A}$ significant but elusive indirect component of biofuel emissions are those resulting from international land use change caused by increased commodity prices due to biofuel production. These indirect emissions have been difficult to quantify because they result from complex market-driven ripple effects that are projected into an uncertain future. ${ }^{4}$ Yet in comparing biofuel emissions with those from gasoline, current regulatory analysis excludes indirect emissions from gasoline and neglects military security emissions that should be considered to directly result from oil consumption. In order to have a balanced assessment of the climate change impacts of substituting biofuels for gasoline, a comparison of all direct and indirect emissions from both types of fuel is required. The analysis presented here contributes to a more complete assessment of total GHG emissions related to gasoline use, by including emissions from military activities related to the protection and acquisition of foreign crude oil.

The United States is truly "addicted to oil." To maintain the current fuel supply, the United States imports 11 million barrels per day

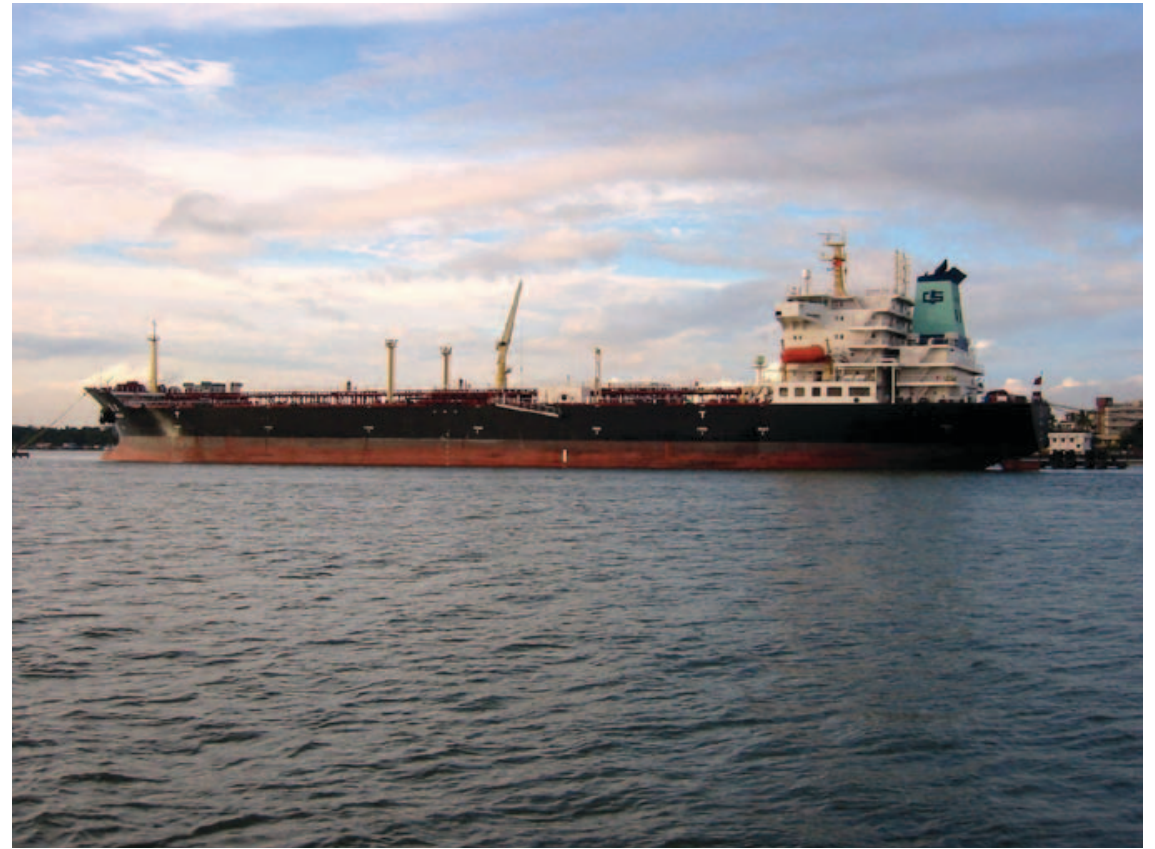

An oil tanker anchored at a refinery in Japan. Wikimedia Commons/Mohan R.

$(\mathrm{mb} / \mathrm{d})$ of crude oil and refined petroleum products (net imports), which is 57 percent of the 19.4 $\mathrm{mb} / \mathrm{d}$ of petroleum consumed in the United States in 2008..$^{5}$ Roughly half of imports and 31 percent of consumption are imported from member states of the Organization of Petroleum Exporting Countries (OPEC) cartel. Imports from the Persian Gulf in the Middle East supplied 18 percent of total imports $(2.37 \mathrm{mb} / \mathrm{d})$ and constituted 12 percent of crude oil used in the United States in 2008. Of the petroleum products used in the U.S. market, 46 percent was in the form of gasoline.

Supertankers transport more than half of globally traded crude oil, and the majority of oil imports to the United States arrive via four supertankers per day. ${ }^{6}$ But this maritime "pipeline" is not free from serious threats. Pirates off the Horn of Africa from Somalia, terrorists, and "rogue" states provide strong justification for the United States to protect oil transportation from volatile regions of the world to the United States and Europe. Some maritime transit routes are particularly hostile and have had a history of disruption, including the Strait of Hormuz, the Suez Canal, and the Gulf of Aden, among others (see Figure 1). In 2003 alone, roughly 100 oil tankers were attacked around the world. ${ }^{7}$ In this article, we estimate the total GHG emissions from military activity related to petroleum. Our analysis first estimates total GHG emissions from the U.S. military, then considers how military activities are related to oil transport and acquisition, and what fraction of these emissions should be attributed to gasoline.

\section{GHG Emissions from U.S. Military Activity in the Persian Gulf}

Following the principles of life cycle assessment (LCA), we evaluate military emissions from both direct fuel consumption and upstream emissions related to the manufacture of materials and equipment procured for military activities. Because conventional military security and activities for the Iraq War have different relationships to oil, we estimate emissions from those two categories separately.

We first estimate the amount of emissions from conventional military activity (excluding the Iraq War), then later estimate the fraction attributable to oil-related ac- 
tivities. The U.S. Energy Information Agency (EIA) reports that total conventional energy use by the U.S. military in 2008 was 889 trillion British thermal units (Btu), the majority of which was from petroleum products, but also included considerable amounts of electricity and natural gas. We use estimates of average emissions from each of these categories to calculate total emissions from this energy use, which amounts to about 85 million metric tons (MMt) of carbon dioxide equivalent $\left(\mathrm{CO}_{2} \mathrm{e}\right)$ (see Table 1$)$. We estimate that an additional $87 \mathrm{MMt}$ was emitted in connection with manufacturing of materials, equip- ment, military infrastructure, vehicles, and munitions. Recent estimates of the GHG emissions from manufacture of these categories are unavailable, but emissions are certainly sizable given that 14.4 percent of U.S. industrial employment was in the defense industry in 1992. ${ }^{8}$ Employment in the defense industry is predominantly in the southern "Gunbelt" states of California, Texas, and Florida. ${ }^{9}$ Expenditures on military acquisitions totaled about $\$ 246$ billion in 2009, and the EIA reports an emissions factor of 0.300 million tons of $\mathrm{CO}_{2}$ e per billion dollars of goods produced in the manufacturing sector. We as- sume that this intensity also applies to military acquisitions, which results in the estimate of $87 \mathrm{MMt}$ of emissions resulting from the manufacturing of 2009 military acquisitions. Together, emissions from conventional military fuel use and acquisitions total about $172 \mathrm{MMt}$ of $\mathrm{CO}_{2} \mathrm{e}$ per year. This implies an intensity factor of $0.289 \mathrm{MMt}$ of $\mathrm{CO}_{2} \mathrm{e}$ per billion dollars of conventional U.S. Department of Defense (DoD) expenditures.

According to a recent U.S. Congressional Research Service report, the average annual cost of the Iraq War has been $\$ 93.5$ billion. (Alternatively, the full monetary cost of

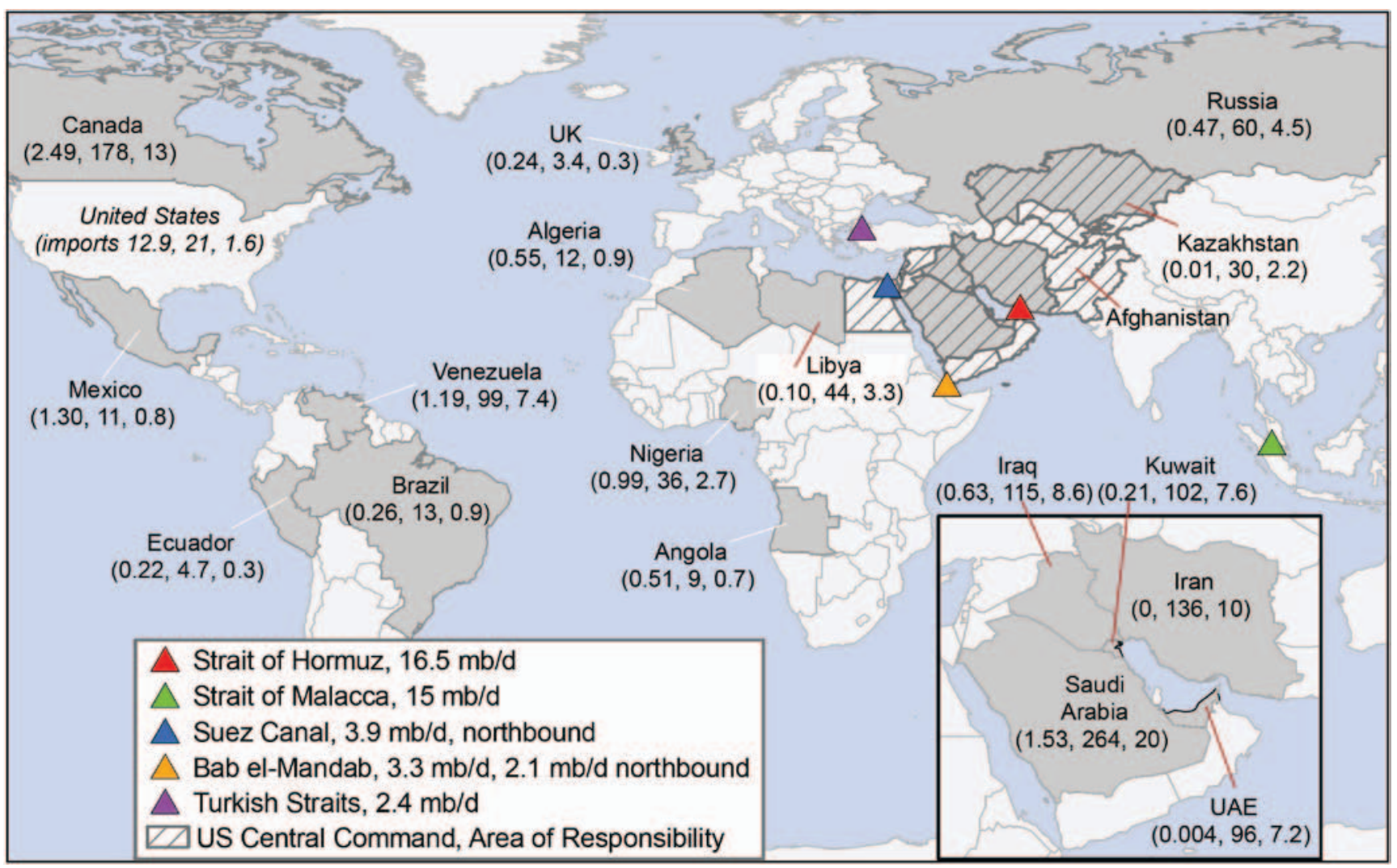

Figure 1. Global supply of U.S. crude oil imports, global oil reserves, maritime oil transit choke points, and the Area of Responsibility for U.S. Central Command. Countries in gray export oil to the U.S. at $>0.2 \mathrm{mb} / \mathrm{d}$ or have $>20$ billion barrels of oil reserves. Country labels in parentheses indicate: 1) U.S. imports designated in $\mathrm{mb} / \mathrm{d}$, 2) oil reserves in billion barrels, and 3) the percentage of global reserves. Oil shipping rates at maritime choke points are for 2006.

Sources: U.S. Energy Information Administration, World Oil Transit Chokepoints (Washington, DC, 2008), http://www.eia.doe.gov/cabs/ World_Oil Transit_Chokepoints/Background.html (accessed 11 February 2010); Reserves from U.S. Energy Information Administration, Annual Energy Review 2008, DOE/EIA-0384(2008) (Washington, DC, 2009), p. 313; Imports from U.S. Energy Information Administration, U.S. Total Crude Oil and Products Imports, http://tonto.eia.doe.gov/dnav/pet/pet_move_impcus_a2_nus_ep00_im0_mbblpd_a.htm (accessed 15 February 2010). 
the Iraq War was projected by Stiglitz and Bilmes (2008) to range between \$2.7 to \$5 trillion dollars, including more complete "resetting" of military infrastructure and other indirect costs such as veterans' healthcare. ${ }^{10}$ ) As there is no additional information on the composition of these war expenditures, we utilize the 0.289 intensity factor calculated for conventional military expenditures to approximate the emissions related to the war at $27 \mathrm{MMt}$ per year. (We suspect that war expenditures are more heavily weighted toward high-emission items such as fuel, munitions, vehicles, and concrete than conventional military expenditures, but we have no data that would support calculation of a separate intensity for war expenditures.) In addition to the kinds of emissions embodied in the 0.289 intensity factor, Reisch and Kretzmann (2008) have noted a number of additional emissions due to the war. ${ }^{11}$ These emissions include extra supply chain fuel, ce- ment for war installations and repair of war-damaged infrastructure, well fires and flaring that occur during wartime, and fuel for troop deployment. Adding these emissions, we estimate the annual emissions related to the war to be $43.3 \mathrm{MMt}$ $\mathrm{CO}_{2}$ e.

To determine the relevance of these emissions to U.S. gasoline consumption, we now turn to the more difficult issue of connecting the military activity to gasoline use in the United States.

\section{Table I. Estimation of U.S. Military Life Cycle GHG Emissions}

\begin{tabular}{lll} 
Emissions category & Calculations & Emissions, \\
\hline Million Mt $\mathrm{CO}_{2} \mathrm{e}$
\end{tabular}

Direct conventional fuel use by military ${ }^{a}$

Total DOD conventional energy use, 2008 Petroleum use-67\% jet fuel

696 trillion Btu $\times$

Electricity use-primary I (0.069l MMt CO 2 e per trillion $\mathrm{Btu}^{b}$ )

Natural gas and other

0 I trillion Btu $\times$ (0.0600 MMt CO 2 e per trillion $\mathrm{Btu}^{b}$ )

(0.0504 MMt CO 2 e per trillion $\left.\mathrm{Btu}^{b}\right)$

Conventional expenditures for

(\$246c expenditure) $\times$ (0.300 MMt CO $\mathrm{M}_{2}$ e per \$billion in 2002 dollars) acquisitions and infrastructure, 2009c

Total conventional GHG emissions per year 172

Implied conventional DoD emissions factor (MMT $\mathrm{CO}_{2}$ e per billion dollars)

Average annual direct U.S. emissions due to the Iraq War

$\left(\right.$ I $\left.72 \mathrm{MMt} \mathrm{CO}_{2} \mathrm{e}\right) /$

0.289

Annual indirect emissions related to the Iraq Ware

Total annual emissions related to the Iraq War

Sources:

a EIA (2009) $)^{5}$, p. 29, 40, 349.

b Average GHG intensities for transportation, electricity, and industrial sectors, from top to bottom from note 5 , p. 40 , 349; Military electricity use is divided by 0.32 to account for losses in generation and transmission from note 5, p.42-43; Petroleum use was divided by 0.78 to include energy used for production and refining from note $\mathrm{II}$.

c Expenditures for acquisitions and installations ${ }^{62}$, Tables I and 2; emissions factor from EIA (2009) ${ }^{5}$ (T. I 2.4, p. 353), corrected to 2009 dollars (T.DI, p. 383).

d Average FY03-FY09, as reported ${ }^{63}$,Table I.

e Emissions beyond those calculated in the emissions per dollar factor. Includes supply chain fuel, troop deployment, cement, well fires and flaring. " 


\section{Oil Production Trends, the Economy, and U.S. Military Activity in the Persian Gulf}

A number of considerations support the contention that a considerable portion of conventional military activity, and even the Iraq War itself, has been for the purpose of securing access to Persian Gulf petroleum supplies and maintaining a low petroleum price for U.S. markets. After World War II, discovery of oil in the Middle East and declining British influence stimulated more regional U.S. involvement. In 1945, the U.S. military established an air base at Dhahran, Saudi Arabia, as a first step for securing oil from the region. ${ }^{12}$ By 1979, the Iranian Revolution and the Soviet invasion of Afghanistan led the U.S. military to take more aggressive steps to build a military infrastructure in the region in order to ensure the flow of oil. The Carter Doctrine (1980) explicitly established the Middle East and its oil supply as "vital interests" of the U.S. economy and explicitly threatened military force to protect the area from regional adversaries. The military buildup in the region culminated in 1983 with the formation of U.S. Central Command, whose objectives were to ensure western access to oil, maintain regional stability, and deter Soviet influence (Figure 1). ${ }^{13}$ The U.S. military now protects global maritime transit routes for oil, although with primary focus on the Persian Gulf.

\section{Peak Oil and the U.S. Economy}

There are now growing concerns that global production of easily accessible oil is nearing its maximum rate. ${ }^{14}$ Global oil production is dominated by giant oil fields with the 500 largest fields contributing over 60 percent of production..$^{15}$ In 2008,580 of the 651 largest oil fields globally were reported to have passed their peak production rate and are now producing an average of about 5-6 percent less oil each year. ${ }^{16}$ Based on these findings, the International Energy Agency (IEA) in 2008 stated "the era of cheap oil is over." ${ }^{17}$
Based on decline rates, global oil production is predicted by researchers at Uppsala University in Sweden to decline from $84 \mathrm{mb} / \mathrm{d}$ (including natural gas liquids) in 2007 to roughly $76 \mathrm{mb} / \mathrm{d}$ by $2030 .{ }^{18}$ Alternatively, official estimates from the IEA optimistically anticipate that total liquid petroleum production (including natural gas liquids and unconventional sources) will continue to increase through 2030, reaching a level 20 percent higher than current levels (see Figure 2). ${ }^{19}$ The U.S. Department of Energy anticipates an increase over this period of about 15 percent. According to the IEA, the share of global production from OPEC countries will rise from 46 percent in 2007 to 56 percent in 2030. Saudi Arabia is projected to remain the world's largest producer throughout the period, its output increasing from $10.2 \mathrm{mb} / \mathrm{d}$ in 2007 to $15.6 \mathrm{mb} / \mathrm{d}$ in 2030. Yet, Saudi Arabia produced only $7.9 \mathrm{mb} / \mathrm{d}$ in 2009 due to OPEC production cuts to maintain oil prices during the global recession. ${ }^{20}$
From 2000 to 2030, the largest gains in petroleum production are projected to come from two key regions: the Middle East and Central Asia (see Table 2). In fact, 94 percent of increases in production over this period are expected to come from 10 nations, with Iraq and Kazakhstan as two of the top four countries with the largest production increase-both are connected to U.S. military operations. Increasing production of nonconventional sources of petroleum such as oil (tar) sands from Canada will also help maintain petroleum supply. Oil sands could contribute as much as 20 percent of the U.S. gasoline supply by $2020 .^{21}$

Increasing oil demand driven by developing economies such as China, along with declining or slower increases in production, will cause oil prices to climb. The average oil price projected in 2008 for the period 2008-2015 is $\$ 100$ per barrel, which is significantly higher than the roughly $\$ 20$ per barrel average oil price over the past half century. By 2030, both the IEA and EIA

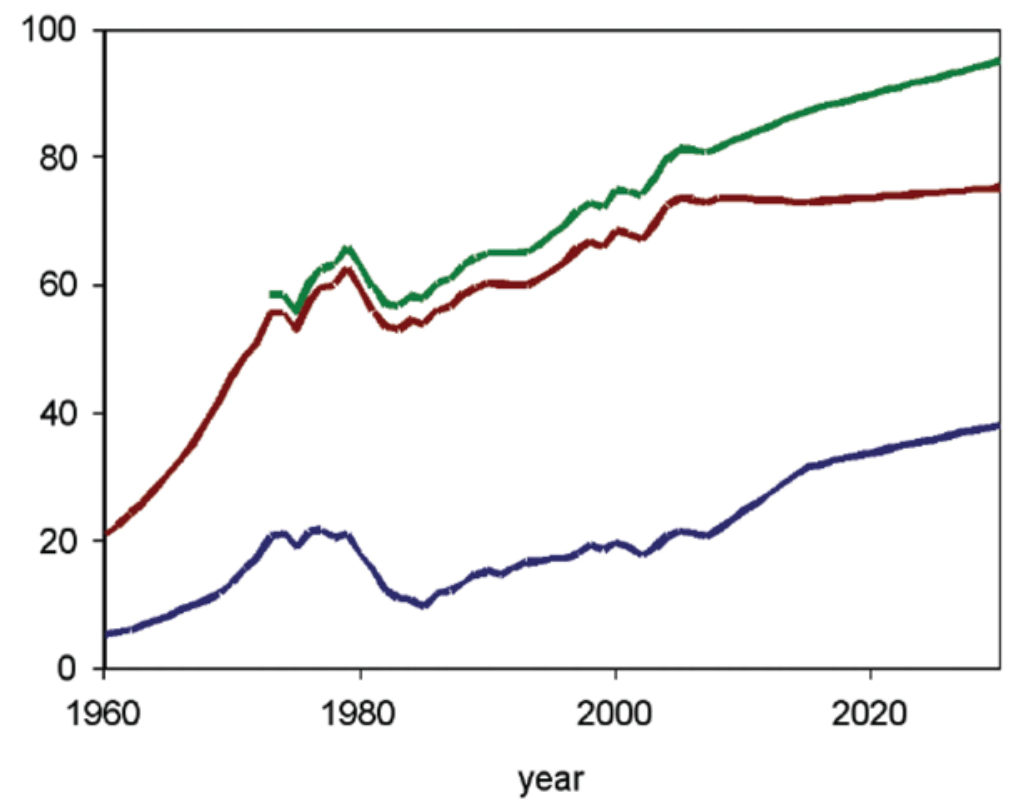

Figure 2. Historical global production of crude oil and the contribution from the Middle East, with projections to 2030, in million barrels per day. Global crude oil (red), crude oil plus natural gas liquids (green), and the contribution of the Persian Gulf (blue). Persian Gulf projection from 2015 and 2030 are for crude oil plus NGL. Source: U.S. Energy Information Administration, Annual Energy Review 2008, DOE/ EIA0384(2008) (Washington, DC, 2009), pp. 315, 317; Projections from International Energy Agency, World Energy Outlook 2008 (Paris, France: OECD/IEA, 2008), p. 251. 
project oil to reach $\$ 170-190$ per barrel in nominal dollars (\$115-\$130 in 2008 dollars). ${ }^{22}$ Some suggest, however, that the recent oil price spike in 2008 to $\$ 147$ per barrel (compared to roughly $\$ 80$ per barrel in March 2010) has stimulated greater conservation and adaptation, which may keep oil prices relatively lower in the near term due to reduced demand. ${ }^{23}$ The current global recession has temporarily reduced demand for oil, and it is difficult to know how quickly this impact will fade.

The cost of importing foreign oil to the U.S. will continue to increase along with projected increases in oil prices (see Figure 3). In 2007 with oil at $\$ 70$ dollars per barrel, the U.S. trade deficit in petroleum products was $\$ 293$ billion, or 36 percent of the total trade deficit of $\$ 819$ billion. ${ }^{24}$ The high oil prices of 2008 transferred a record of nearly $\$ 1$ trillion dollars to members of OPEC. ${ }^{25}$ Regarding the prospects for such transfers in the future, consider that the national oil companies in OPEC member states and other countries (e.g., Saudi Aramco and National Iranian Oil Company) control approximately 90 percent of the world's oil reserves and 75 percent of global oil production; similar numbers apply for natural gas. ${ }^{26} \mathrm{On}$ the other hand, the reserves of major international oil companies (such as Exxon-Mobil, ConocoPhillips, Chevron, BP, and Shell) were projected in 2004 by the U.S. Federal Trade Commission to be depleted by 2015-2017, if their reserves are not expanded. ${ }^{27}$

If the oil supply were disrupted, accompanying price spikes would lead to significant negative impacts on the global economy. ${ }^{28}$ While the interrelationships between the business cycle and petroleum price are complicated and not easily resolved, Brown and Huntington report that 10 of the 11 U.S. recessions since World War II have been preceded by significant oil price spikes. ${ }^{29}$ The relationships between oil price and the health of the economy suggest that maintaining low and stable oil prices is a political imperative associated with modern petroleum-fueled economies.

Military professionals recognize the significance of these changes in the oil economy for military preparedness. Professors at the U.S. Naval Postgraduate School recently stated, "The idea of peak oil is already becoming established as a subtext or unspoken assumption among strategists and policymakers ...," and it was further noted that "The possibility that access to energy resources may become an object of large-scale armed struggle is

Table 2. Crude Oil and Natural Gas Liquids Production and Projections Regionally and for Selected Countries

\begin{tabular}{|c|c|c|c|c|c|c|}
\hline \multicolumn{7}{|l|}{ Regional Oil Production } \\
\hline & 2000 & 2007 & 2015 & 2030 & \multicolumn{2}{|c|}{$\Delta 2000-2030$} \\
\hline & \multicolumn{5}{|c|}{$\mathrm{mb} / \mathrm{d}$} & $\%$ \\
\hline Middle East-OPEC* & 21.3 & 22.3 & 30.3 & 37.1 & 15.8 & 74 \\
\hline Central Asia & 8.1 & 12.9 & 14.3 & 16.5 & 8.4 & 104 \\
\hline Non-Middle East-OPEC§ & 10.7 & 12.2 & 13.6 & 15 & 4.3 & 40 \\
\hline Latin America & 3.2 & 3.5 & 5.0 & 4.5 & 1.3 & 41 \\
\hline Asia & 5.6 & 6.4 & 5.8 & 5.1 & -0.5 & -9 \\
\hline North America & 13.3 & 12.5 & II.I & 11.4 & -1.9 & -14 \\
\hline Europe & 6.8 & 4.9 & 3.3 & 2.1 & -4.7 & -69 \\
\hline \multicolumn{7}{|c|}{ Countries-Highest Increases } \\
\hline Saudi Arabia & 9.3 & 10.2 & 14.4 & 15.6 & 6.3 & 68 \\
\hline Canada (oil sands only) & 0.6 & 1.2 & 3.3 & 5.9 & 5.3 & 883 \\
\hline Iraq & 2.6 & 2.1 & 3.0 & 6.4 & 3.8 & 146 \\
\hline Kazakhstan & 0.7 & 1.4 & 2.4 & 4.3 & 3.6 & 514 \\
\hline Brazil & 1.3 & 1.8 & 3.5 & 3.4 & 2.1 & 162 \\
\hline Angola & 0.7 & 1.7 & 2.3 & 2.6 & 1.9 & $27 \mid$ \\
\hline Iran & 3.8 & 4.4 & 4.5 & 5.4 & 1.6 & 42 \\
\hline Nigeria & 2.2 & 2.3 & 3.4 & 3.7 & 1.5 & 68 \\
\hline Kuwait & 2.2 & 2.6 & 2.9 & 3.3 & I.I & 50 \\
\hline Venezuela & 3.1 & 2.6 & 2.7 & 3.6 & 0.5 & 16 \\
\hline
\end{tabular}

* Iran, Iraq, Kuwait, Qatar, Saudi Arabia, United Arab Emirates. $\S$ Algeria, Angola, Ecuador, Indonesia, Libya, Nigeria, Venezuela. Source: International Energy Agency, World Energy Outlook 2008 (Paris, France: OECD/IEA, 2008), pp. $267,272$. 


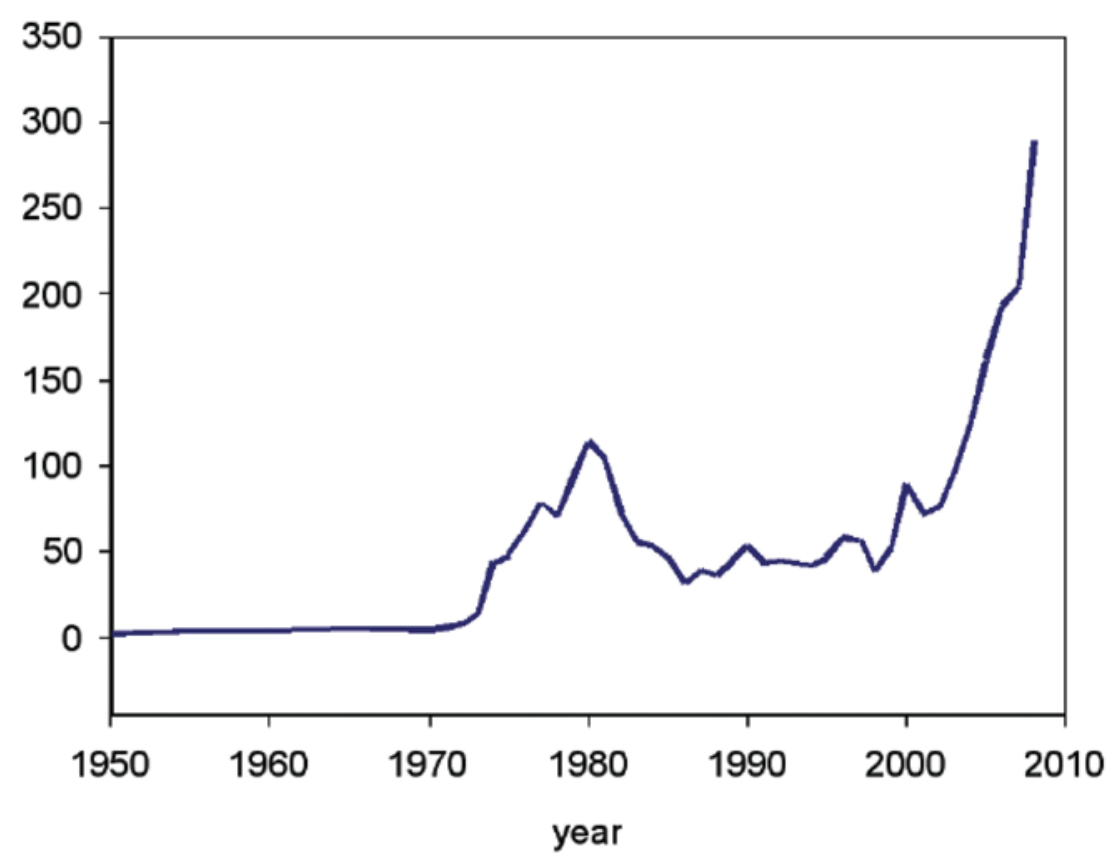

Figure 3. Inflation-adjusted annual value of U.S. imports of crude oil in billions of dollars. Constant dollars valued in the year 2000.

Source: U.S. Energy Information Administration, Annual Energy Review 2008, DOE/ EIA0384(2008) (Washington, DC, 2009), p. 81.

almost incontestably the single most alarming prospect facing the international system today." 30

\section{Oil and the Iraq War}

Many reasons may have led the United States to invade Iraq in 2003. Initially, the Bush administration asserted that national security concerns were primary. Threats from Iraq included the potential existence of weapons of mass destruction (WMD) (justification 1) and Iraq's possible support of terrorism, as viewed after post-September 11, 2001 (justification 2). Based on the Downing Street memo, it now appears that the U.S. administration had already decided to invade Iraq by July 23, 2002, prior to the re-entry of U.N. weapons inspectors back into the country and before the WMD threat could be evaluated. ${ }^{31}$ In February 2003, the month immediately preceding the U.S. invasion, the U.S. administration asserted that democratization of Iraq was another reason for invasion (justification 3) and would foster a larger political transformation of the Middle East (justification 4). ${ }^{32}$ Following the 1991 Persian Gulf War, billion barrels (about 9 percent of global crude oil reserves), following only Saudi Arabia and Iran in size, and some evidence suggests that Iraq's reserves may be larger than twice the proven amount. ${ }^{37} \mathrm{Re}$ gime change was thought to enable Iraq to produce more oil and make the United States less dependent on Saudi Arabia. ${ }^{38}$ Some have asserted that the U.S. government ultimately sought to limit Iraq's influence over the Middle East and OPEC in order to control oil prices more favorably for the U.S. economy. ${ }^{39}$

Viewed from the perspective of peak oil and the overwhelming majority of reserves under the control of national oil companies and OPEC nations, and the fact that a significant rise in oil price could cripple the U.S. economy, the assertion that the U.S. invasion of Iraq sought to control access to oil with the aim to control oil prices appears to carry substantial weight. There is now growing consensus among economic, foreign policy, and military analysts that oil played a large part in the United States. led invasion of Iraq, ${ }^{40}$ even though official statements from the U.S. government deny such claims. In 2007, former U.S. Federal Reserve Chairman Alan Greenspan clearly articulated the critical place of oil in the global economy and its relationship to the U.S. invasion:

I am saddened that it is politically inconvenient to acknowledge what everyone knows: the Iraq War is largely about oil. Thus, projections of world oil supply and demand that do not note the highly precarious environment of the Middle East are avoiding the eight-hundred-pound gorilla that could bring world economic growth to a halt. ${ }^{41}$

In hindsight, the U.S. invasion of Iraq has been viewed by many as a "war of choice" not a "war of necessity." It has been asserted that the Iraq invasion was a unilateral preventive war that could have been avoided through the use of other viable policy alternatives. ${ }^{42}$ When viewed in a historical perspective, it was clearly understood by U.S. military personnel in U.S. Central Command that "the invasion of Iraq is 
only the latest in a series of military engagements in the Gulf proceeding from the Carter Doctrine," 43 which clearly places its roots in oil.

Many documents preceding the U.S. invasion provide insight into the thinking of policymakers at the time. In 2001, the U.S. National Energy Policy Development Group (NEPD) provided an energy outlook for a country increasingly dependent on Middle Eastern oil: "By 2020, Gulf oil producers are projected to supply between 54 and 67 percent of the world's oil ... The Gulf will be a primary focus of U.S. international energy policy..." and "The NEPD Group recommends that the President support initiatives by Saudi Arabia, Kuwait, Algeria, Qatar, the UAE, and other suppliers [Iraq] to open up areas of their energy sectors to foreign investment." 44 In addition to this document, other related documents before the invasion indicate an intense interest by the multinational oil companies and the Bush administration to gain better access to Middle Eastern oil. For example, the Bush administration discussed the logistics of a military invasion of Iraq in its first national security meeting in 2001, two years before its invasion. ${ }^{45}$ Now, after the U.S. invasion and implementation of a new government, multinational oil companies (e.g., Exxon, BP) are establishing new contracts in Iraq that will extend the lifetime of their companies.

\section{Attributing Military Emissions in the Persian Gulf to U.S. Gasoline Consumption}

Life cycle assessment (LCA) has incorporated two approaches to attributing emissions to industrial processes, namely, the attributional and consequential approaches. ${ }^{46}$ Attributional LCA is an analytical approach in which emissions from various components in a production process, from acquisition of raw materials to final product use, are inventoried and attributed to a single product or allocated to one product (e.g., fuel) in proportion to its share of all products from a multiproduct system, measured alternatively in terms of the fraction of energy, mass, or value. The consequential LCA approach attempts to identify the total marginal change in emissions that would occur as a consequence of some change in the output of the product. The attributional approach is an accounting exercise, and it is not without its conceptual and assessment difficulties. The consequential LCA approach is even more difficult, because in addition to the accounting assessment, it demands an assessment of all changes in human behavior that would result from the change in fuel use, if that behavioral change would also result in a significant emissions change. Of course, it is this total impact on GHG emissions that is relevant to climate change and so to public policy, but these prospective changes in behavior may include quite distant ripple effects that are impossible to assess without a considerable amount of judgment, given that it involves uncertain changes in human behavior, as well as the usual difficulties in emissions accounting.

\section{Attributing Military Security Emis- sions to U.S. Gasoline}

Life cycle GHG emissions calculations associated with U.S. gasoline production and use have included emissions from the extraction and shipping of oil as well as combustion, but related military security emissions have been omitted as direct components of the production life cycle. ${ }^{47}$ These calculations have been faulty because warships are to oil what combine harvesters are to biofuels. Where combines are mechanical components that use fossil fuels to collect and deliver crops to produce biofuels, the military today is essential for collecting oil from distant regions and delivering it for gasoline production: both are direct supply chain operations that must be included in the LCA of these products. Recent U.S. federal law and government documents make this clear, as does common sense, given the clear security issues associated with maritime oil trade today.

The U.S. Security and Accountability for Every (SAFE) Port Act of 2006 calls on the United States to "develop, implement, and update, as appropriate, a strategic plan to enhance the security of the international supply chain ... [and] provide measurable goals, including objectives, mechanisms, and a schedule, for furthering the security of commercial operations from point of origin to point of destination." ${ }^{48}$ According to a U.S. Government Accountability Office report in 2007 regarding oil and gas tankers specifically, "successful attacks abroad, the expressed desire by terrorists to target U.S. economic interests, and the potential outcome of a terrorist attack on a tanker have led Congress and the Administration to conclude that protective efforts are warranted." 49 The DoD was explicitly identified in the report as responsible to maintain "... a credible maritime interdiction capability to deal with identified hostile ships at any location when authorized to do so." Furthermore, in addition to the DoD, the total security activities coordinated among the U.S. Coast Guard, U.S. Federal Bureau of Investigation, and U.S. Department of Homeland Security were found to be inadequate, stressing the need for more investment in security: "Much is being done, both internationally and domestically, to protect energy commodity tankers and their attendant facilities from attack, but notwithstanding these actions, significant challenges may still leave tankers and facilities at risk." 49

The analysis presented in the sections above, federal law, and these statements combine to clearly indicate that today, military security is within the boundaries of the gasoline production process. Whereas previous assessments have drawn the boundaries with military security on the outside of the petroleum life cycle, attributional LCA of GHG emissions must now be updated by regulators to reflect that military security is within the direct operational boundaries of the petroleum supply chain.

Several studies have estimated the fraction of military expenditures attributable to securing oil supplies, from which we may be able to in- 


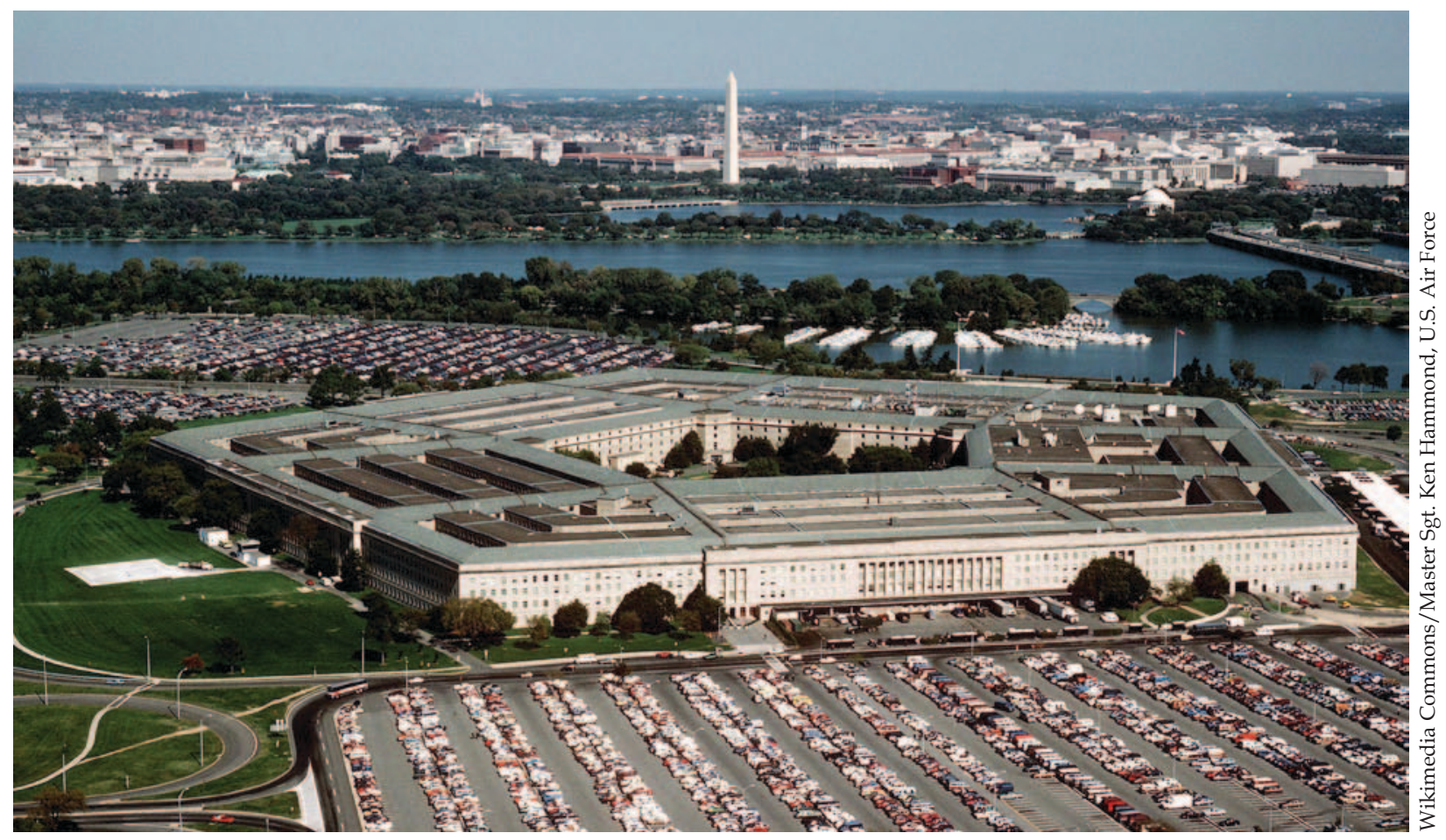

fer the fraction of GHG emissions. These estimates suggest that $\$ 27$ to $\$ 138$ billion dollars is spent annually by the U.S. military for protection of Middle Eastern maritime oil transit routes and oil infrastructure, with an average of $\$ 84$ billion dollars per year. ${ }^{50}$ The most recent analysis from the National Priorities Project estimates oil-related military costs for 2009 based on primary materials including unclassified military strategy documents, posture statements, testimony by DoD officials, and DoD statistics. Two different methods were used in their analysis. The first method uses a global forceplanning approach which accounts for having to fight two major wars simultaneously (e.g. Persian Gulf and North Korea), and allocates 40 percent of U.S. conventional military costs to the Middle East, and then attributes 75 percent of those costs to oil alone resulting in $\$ 97$ billion of an estimated $\$ 517$ billion DoD budget of 2009. The second estimate attributes the fraction of three regional U.S. Unified Commands (e.g. Central, European, and Pacific Commands) to oil security, which results in an estimate of $\$ 104$ billion dollars for global protection of oil. Based on these two approaches, we therefore conclude that about 20 percent of the conventional DoD budget is a reasonable estimate of the fraction of emissions attributable to the objective of oil security.

This 20 percent attribution rate implies that of the annual conventional military emissions, approximately $16 \mathrm{MMt} \mathrm{CO}_{2} \mathrm{e}$ per year can be attributed to oil security (see Table 3); or 0.2 percent of total U.S. emissions at $6957 \mathrm{MMt} \mathrm{CO}_{2} \mathrm{e}$ in $2008 .{ }^{51}$ We estimate that 61 billion liters of gasoline (46.1 percent by volume) were derived from the 787 million barrels of petroleum the United States imports per year from the Persian Gulf on average from 2005 to 2009, so attributing this fraction of the Gulf oil security emissions to gasoline imports implies that $8.1 \mathrm{~g}$ $\mathrm{CO}_{2} \mathrm{e}$ of emissions are associated with each megajoule (MJ) of Gulf gasoline (Table 3 ). This is equivalent to roughly 8 percent of the current base emissions attributed to a MJ of energy in gasoline used in the United States.

In an alternative calculation, the consequential LCA approach asks by how much these military emissions would be reduced if the United States were to sufficiently reduce gasoline consumption to eliminate Persian Gulf imports. It was recently asserted that if the United States stopped imports from the region, U.S. military infrastructure in the Middle East would disappear. Retired U.S. colonel and Boston University professor Andrew Bacevich recently stated:

Imagine the impact just on the Pentagon [DoD] were this country actually to achieve anything approaching energy independence. U.S. Central Command would go out of business. Dozens of bases in and around the Middle East would close. The navy's fifth fleet would stand down. Weapons contracts worth tens of billions would risk being canceled. ${ }^{52}$

Such a reduction in imports may occur over a 20-year timeframe. Production of 57 billion liters per year (bly) of ethanol from corn, as mandated by EISA legislation, would be approximately sufficient to substitute for the 61 bly of gasoline from Middle East oil imports averaged from 2005 to 2009. The elimination of Middle East oil imports would allow cessation of military oil security activity, equivalent to a 20-percent reduction in conventional U.S. military activity 
Table 3. Oil-Related Military GHG Emissions from Gasoline by Attributional and Consequential LCA Approaches

$\begin{array}{cccc}\begin{array}{c}\text { Oil Security, } \\ \text { Attrib. }\end{array} & \begin{array}{c}\text { Oil Security, } \\ \text { Conseq. }\end{array} & \begin{array}{c}\text { Iraq War, } \\ \text { Attrib. }\end{array} & \begin{array}{c}\text { Oil Security + } \\ \text { Iraq War, Attrib. }\end{array}\end{array}$

Annual oil-related military emissions ${ }^{a}$

$\begin{array}{lllll}\left(\mathrm{MMt} \mathrm{CO}_{2} \mathrm{e} \mathrm{yr}^{-1}\right) & 34.4 & 34.4 & 43.3 & 77.8\end{array}$

\section{Oil-related military emissions per MJ of gasoline from Persian Gulf imports}

U.S. petroleum imports from the Persian Gulf, average 2005-2009b (M. bbl $\mathrm{yr}^{-1}$ )

Gasoline from above imports, at 76.8 liters/barrel ${ }^{c}$

(b. liters $\mathrm{yr}^{-1}$ )

Military emissions allocated to gasoline, $46.1 \%$ of volume $\left(\mathrm{MMt} \mathrm{CO}_{2}{\left.\mathrm{e} \mathrm{yr}^{-1}\right)}^{-1}\right.$

Military emissions allocated to gasoline, $100 \%$ of volume (MMt CO $\mathrm{Ce} \mathrm{rr}^{-1}$ ) 34.4

Military emissions per liter of Gulf gasoline $\left(\mathrm{g} \mathrm{CO}_{2} \mathrm{e}^{-1}\right)$

569

331

593

Military emissions per $\mathrm{MJ}$ of Gulf gasoline energy,

$$
\text { at 32.6 MJ per liter }\left(\mathrm{g} \mathrm{CO}_{2} \mathrm{e} \mathrm{MJ}^{-1}\right)
$$

17.5

Base lifecycle emissions of gasoline ${ }^{d}$

$$
\left(\mathrm{g} \mathrm{CO}_{2} \text { e } \mathrm{MJ}^{-1}\right. \text { ) }
$$

97.7

97.7

Military emissions plus base emissions

$$
\text { (g } \mathrm{CO}_{2} \text { e } \mathrm{MJ}^{-1} \text { ) }
$$

$8 \%$

115.2

107.8

115.9

Percent increase over gasoline base, \%

$18 \%$

$10 \%$

\section{Oil-related military emissions per MJ for all U.S. gasoline}

Total gasoline consumption in the U.S. in 2009

(b. liters $\left.\mathrm{yr}^{-1}\right)^{\mathrm{e}}$

Military emissions per liter of all U.S. gasoline

$$
\left(\mathrm{g} \mathrm{CO}_{2} \mathrm{e}^{-1}\right)
$$

98.6

99.7

98.9

99.8

$$
\text { (g CO} 2 \text { e } \mathrm{MJ}^{-1} \text { ) }
$$

$1.0 \%$

$2.1 \%$

$1.2 \%$

$2.2 \%$

Sources:

a $20 \%$ of conventional emissions, $100 \%$ of war emissions in Table I.

b EIA, Petroleum Supply Monthly, T.52, accessed online 3/I I/20 I0.

c Average yield of gasoline from petroleum in $2009=46.1 \%$ (EIA, Petroleum Supply Monthly, T.34, accessed March I I, 20 I0). $d$ note I.

e Total gasoline supplied 2009, I 38 b. gal = 522 b. I (EIA, Petroleum Supply Monthly, T. I, accessed online March I I, 20 I0). 
and emissions, which in turn is equivalent to $17.5 \mathrm{~g} \mathrm{CO}_{2} \mathrm{e}$ per $\mathrm{MJ}$ of gasoline energy now imported from the Middle East (Table 3). If this consequence is a plausible and reasonable prediction, regulatory authorities should include these indirect military emissions as they compare the GHG consequences of substituting biofuels for gasoline from the Persian Gulf.

We note that this $18 \mathrm{~g} \mathrm{CO}_{2}$ e per MJ of gasoline energy from military security is roughly equivalent to the 14 to $27 \mathrm{~g} \mathrm{CO}_{2}$ e per MJ currently attributed to corn ethanol energy due to consequential indirect land use change. ${ }^{53}$ We further suggest that the confidence interval around our estimate is comparable to the confidence interval on the latter figures. ${ }^{54}$ The key uncertainties in our estimate are associated with the total direct costs of military security for petroleum infrastructure and transit routes, including U.S. Coast Guard and other agencies (which are likely to be greater than our estimate of emissions from the military alone); emissions from the U.S. military-industrial complex (an area that has recently received little attention); and whether the elimination of Middle East imports would result in a 20 percent reduction of conventional military activity. ${ }^{55}$

It can also be argued that imports might be reduced by only 50 percent instead of completely, and in that case we would expect little if any reduction in oil security activity, given that no less effort may be required to provide safe passage for half of current ships compared to all of them. It can also be argued that if the United States reduced or eliminated its dedication to oil security in the Middle East, another country would increase its own efforts for that purpose, thus offsetting the climate change impact of eliminating U.S. imports from the area. These ambiguities highlight the difficulties of predicting human behavior that would result from a change in U.S. fuel use-difficulties common to all consequential LCA analyses. We have implicitly excluded those possibilities as behavioral outcomes-

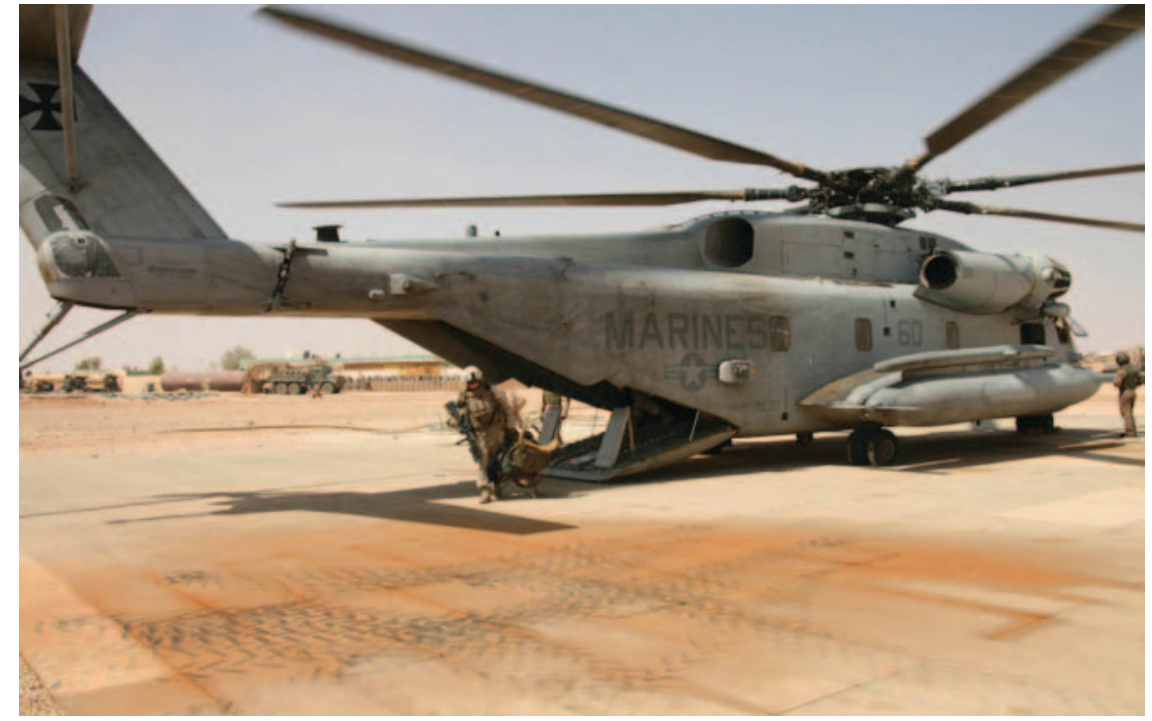

US Marine Corps CH 53 Helicopter at Camp Korean Village, Iraq. Official U.S. Marine Corps Photo by Capt. Paul Greenberg

assigned probabilities of zero to them. To that extent, our evaluation is an incomplete analysis on which to base fuel policy. We hasten to point out, however, that current regulatory decisions are already based on similarly incomplete analysis, which results in an unbalanced consideration of the likely impacts of substituting one fuel for the other. Specifically, the 14 to $27 \mathrm{~g} \mathrm{CO}_{2} \mathrm{e}$ per MJ currently attributed to corn ethanol energy due to indirect land use change is based on the assumption that 57 bly of ethanol produced in the United States will drive land use change abroad, with zero probabilities assigned to alternative outcomes, and zero probability assigned to the prospect that land use regulations or forest retention programs might alter marketdriven levels of conversions of forests to crops as a result of that additional production, etc.

Given that the indirect land use emissions currently attributed to biofuels and the military security emissions attributed here to Gulf gasoline are based on similarly incomplete analyses of alternative behavioral outcomes, it would be correct for the U.S. EPA to include these estimates for both fuels. This would help base the emissions comparison on assessments of single outcome behavioral consequences of a change in fuel use, and so provide a balanced assessment of likely consequences for climate change. Coincidentally, these military emissions due to gasoline are roughly equal to land use emissions attributed to corn ethanol in a hypothetical, but probable, future. Yet, this attribution would only be accurate for the comparison of corn-ethanol with the fraction of gasoline derived from Middle Eastern imports. A comprehensive fuel policy should attribute emissions to each different source of petroleum, as is done for biofuels (gasoline from petroleum is currently assigned only an average value).

\section{Iraq War Emissions and U.S. Gasoline}

The fraction of Iraq War emissions that should be attributed to the use of petroleum is another difficult matter to judge. In Table 3, we calculate and report that the amount of these emissions is equivalent to 10.1 $\mathrm{g} \mathrm{CO}_{2} \mathrm{e}$ per MJ of Gulf gasoline consumed in the U.S. (or equivalent to $1.2 \mathrm{~g} \mathrm{CO}_{2} \mathrm{e}$ per MJ of all gasoline consumed in 2009 as a reference). This amounts to 10 percent of the current base GHG emissions established for gasoline. From an attributional LCA viewpoint, based on the economic importance of oil and other findings discussed above, it is reasonable to 


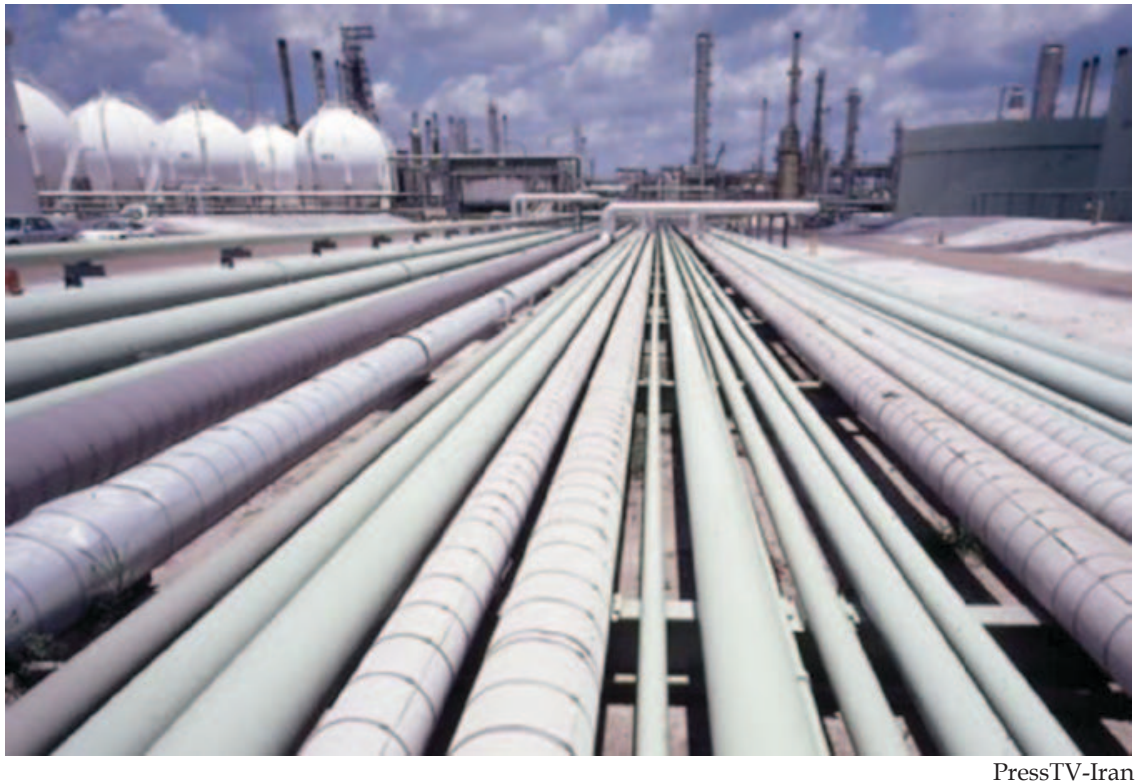

attribute perhaps 75 percent to 100 percent of the war to oil, and 46 percent of this amount to gasoline. But so far, little oil has flowed from Iraq to the United States.

From a consequential LCA perspective, however, what is relevant to future policy is the likely reduction in war activity that would occur as a consequence of reduced U.S. consumption of gasoline, relative to likely war activity with imports continuing at their current levels. Suppose, for example, that the likelihood of war in the area in the future is 15 percent with current U.S. gasoline consumption, but only 5 percent with no U.S. imports from the Persian Gulf. The expected emissions reduction due to this change in policy would then be 10 percent of 43 MMt of war-related $\mathrm{CO}_{2}$ e emissions, equivalent to $1.0 \mathrm{~g} \mathrm{CO}_{2} \mathrm{e}$ per $\mathrm{MJ}$ and roughly 1 percent of base emissions from gasoline. So, given the difficulties of assigning probabilities to war in the future, plausible evaluations of these indirect war emissions consequentially due to gasoline consumption range from near zero to 10 percent of base gasoline emissions, or perhaps even more.

Overall military emissions associated with gasoline from the Middle East are then found to range from 8.1 to $18.2 \mathrm{~g} \mathrm{CO}_{2} \mathrm{e}$ per MJ, with attributional military security alone at the low end to attributional military security and the Iraq War at the high end; the consequential approach to military security emissions alone is $17.5 \mathrm{~g} \mathrm{CO}_{2} \mathrm{e}$ per MJ. It should also be noted that as petroleum imports decline, the intensity of these emissions would increase if expenditures for military security were to remain constant.

\section{Probable Future Military Activities for Oil}

Current challenges for the petroleum economy include a precarious flow of imports, wealth transfer and contribution to trade deficits, costly military operations, and related international terrorism. ${ }^{56}$ These serious economic and national security issues have recently stimulated support for the development of alternative energy sources in the United States. ${ }^{57}$ In addition to domestic initiatives, the U.S. Air Force, the world's single largest consumer of petroleum, recently announced a plan to substitute 50 percent of its fuel use with alternative fuels, with particular emphasis on biofuels. ${ }^{58}$ Yet, biofuels will be able to supply no more than roughly 25 percent of motor fuel in the foreseeable future, so other regions where oil supplies are available will likely see greater military investment and intervention.

Kazakhstan is of interest because it has one of the largest oil reserves globally (Figure 1), and it is one of the top four countries with the greatest projected increase in production capacity over the next 20 years (Table 2). Kazakhstan contains three of the world's 10 largest giant oil fields (newly discovered), and the country is now Chevron's leading source of petroleum, currently exported via pipelines heading west through Georgia. ${ }^{59}$ As a corollary to Iraq, U.S. military activities in Afghanistan also appear to be at least partially stimulated by oil. Pipelines for transportation of oil and gas from Central Asia to the Indian Ocean are currently planned and have been discussed for at least 15 years. ${ }^{60}$ Such potential pipelines would transport oil from the Caspian region, bypassing Russia and the Turkish Straights, and Iran and the Straight of Hormuz (Figure 1).

In U.S. Congressional testimony in 2006, Steven Mann, Principal Deputy Assistant Secretary for South and Central Asian Affairs at the State Department, clearly outlined U.S. intentions concerning oil in the Afghanistan region:

Since the independence of the new Caspian states 15 years ago, the United States has been in the forefront of oil and gas development in the region, and our efforts are paying off.... With the completion of the first phase of the EastWest Energy Corridor [through Georgia], we must now press on with the second phase of supporting new energy routes out of Central Asia.... The United States and the countries of the broader region share an interest in the free movement of energy, people, goods, and information from the Kazakh steppes to the Indian Ocean. We want not only to support economic development along a north-south axis, but also afford Afghanistan access to a wider world, thus becoming a bridge, not a barrier. ${ }^{61}$

These explicit activities related to oil in the Afghanistan region suggest that further emissions related to military activity there might reasonably be included in the emissions of gaso- 


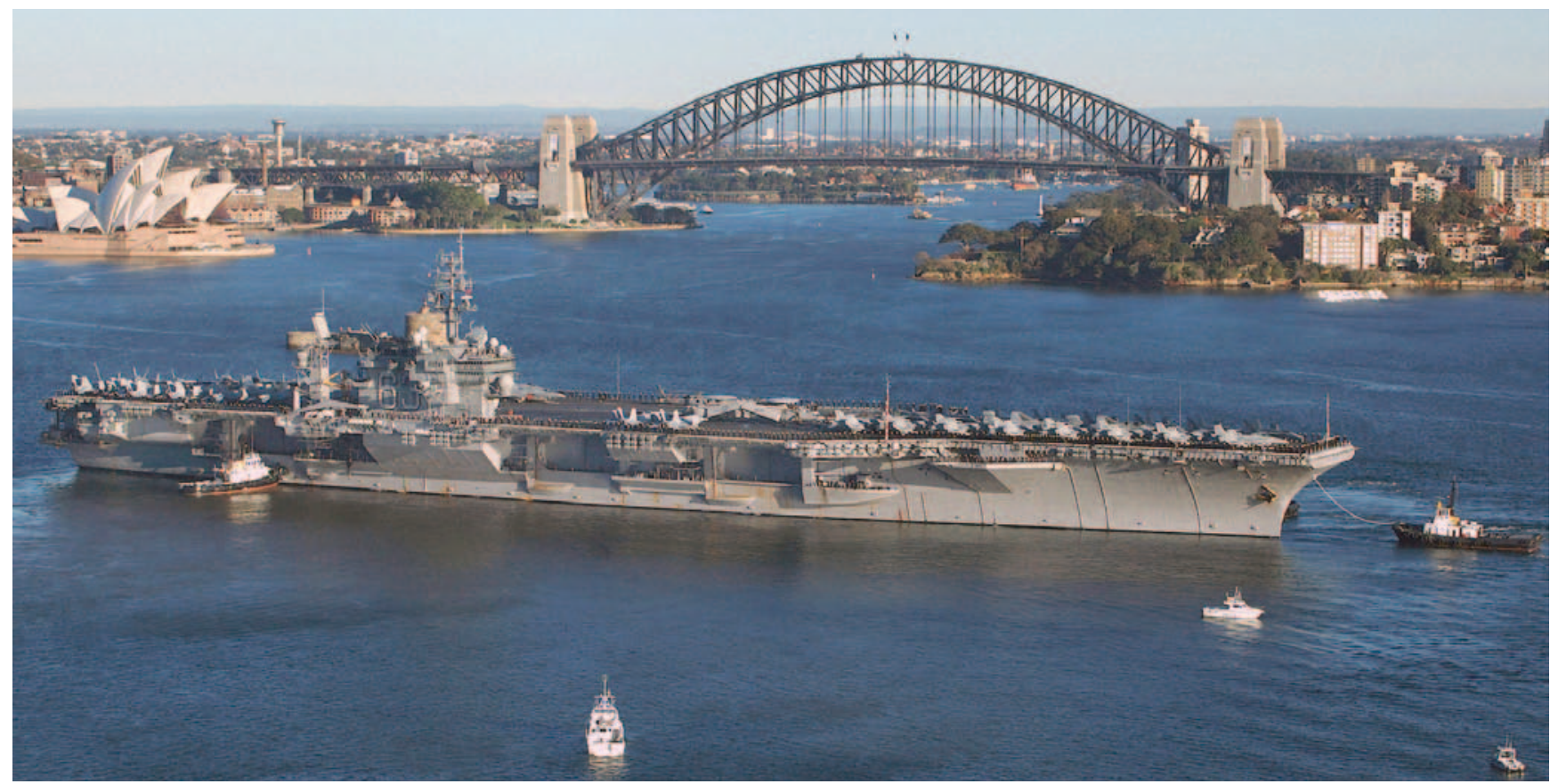

USS Kitty Hawk in Sydney, Australia. Wikimedia Commons/PH2 William H. Ramsey, USN

line, if fuel were to pass through that region to the U.S. This additional case further supports the notion that the military is highly engaged in securing foreign oil today.

The analysis presented here suggests that GHG emissions from military activities should be included in the GHG intensity of gasoline, as the U.S. Environmental Protection Agency implements emissions requirements for biofuels relative to petroleum fuels. For military security emissions related to gasoline use, attributional calculations produce a result nearly half that of consequential calculations, but there is greater uncertainty in allocating additional emissions from the Iraq War.

To accurately determine the degree that biofuels can reduce GHG emissions that contribute to climate change, we must develop a better understanding of U.S. military GHG emissions related to oil acquisition. U.S. fuel policy must be guided by the best possible estimates of the GHG consequences of switching from gasoline to renewable fuels. Emissions changes that indirectly result as consequences of changes in policy must surely be included in rational policymaking, but these emissions can only be estimated with con- siderable judgment and substantial uncertainties. Given that the potential GHG implications of future behavioral change may be quite significant for changes in gasoline use as well as for changes in ethanol use, it is appropriate that they should be considered by regulatory agencies, as well as necessary that they be considered as the 2007 EISA legislation directs.

Adam J. Liska is an Assistant Professor and the George Dempster Smith Chair of Industrial Ecology in the Department of Biological Systems Engineering at the University of Nebraska.

Richard K. Perrin is the Jim Roberts Professor in the Department of Agricultural Economics at the University of Nebraska. This article was supported through research and education grants from the University of Nebraska Center for Energy Sciences Research.

\section{Notes}

1. A. J. Liska and R. K. Perrin, "Indirect Land Use Emissions in the Life Cycle of Biofuels: Regulations vs. Science," Biofuels, Bioproducts, and Biorefining 3, no. 3 (2009): 318-328

2. A. J. Liska, H. S. Yang, V. R. Bremer, T. J. Klopfenstein, D. T. Walters, G. E. Erickson, K. G. Cassman, "Improvements in Life Cycle Energy Efficiency and Greenhouse Gas Emissions of Corn- Ethanol," Journal of Industrial Ecology 13, no. 1 (2009): 58-74; R. Anex and R. Lifset, "Post
Script on the Ethanol Debate: Reaching Consensus?" Journal of Industrial Ecology 13, no. 6 (2009): 996-999.

3. Liska and Perrin, note 1 above.

4. T. W. Hertel, A. A. Golub, A. D. Jones, M. O'Hare, R. J. Plevin, D. M. Kammen, "Effects of U.S. Maize Ethanol on Global Land Use and Greenhouse Gas Emissions: Estimating Market-Mediated Responses," Bioscience 60, no. 3 (2010): 223-231; R. L. Naylor, A. J. Liska, M. B. Burke, W. P. Falcon, J. Gaskell, S. D. Rozelle, K. G. Cassman. "The Ripple Effect: Biofuels, Food Security, and the Environment," Environment 49, no. 9 (2007): 30-43.

5. Petroleum statistics for imports, contributors, and consumption from U.S. Energy Information Administration, Annual Energy Review 2008, DOE/EIA- 0384(2008) (Washington, DC: U.S. Energy Information Administration, 2009), pp. $129,135,149$.

6. U.S. Government Accountability Office, Maritime Security: Federal Efforts Needed to Address Challenges in Preventing and Responding to Terrorist Attacks on Energy Commodity Tankers, GAO08-141 (Washington, DC: U.S. Government Accountability Office, 2007); U.S. Federal Trade Commission Bureau of Economics, The Petroleum Industry: Mergers, Structural Change, and Antitrust Enforcement (Washington, DC: U.S. Federal Trade Commission Bureau of Economics, 2004).

7. A. B. Lovins, E. K. Datta, O.-E. Bustnes, J. G. Koomey, N. J. Glasgow. Winning the Oil Endgame: Innovations for Profits, Jobs, and Security (Snowmass, CO: Rocky Mountain Institute, 2005), p. 11; A map showing attempted and successful maritime highjackings in the Gulf of Aden in 2009 is provided in C. Boucek and D. Donadio, "A Nation on a Brink," Atlantic Monthly 305, no. 3 (2010): 52-53.

8. A. R. Markusen and S. S. Costigan, eds., Arming the Future: A Defense Industry for the 21st Century (New York: Council on Foreign Relations, 1999), p. 341.

9. A. Markusen, P. Hall, S. Campbell, and S. Deitrick, The Rise of the Gunbelt: The Military Remap- 
ping of Industrial America (Oxford: Oxford University Press, 1991), p. 23.

10. J. E. Stiglitz and L. J. Bilmes, The Three Trillion Dollar War: The True Cost of the Iraq Conflict (New York: W.W. Norton \& Company, Inc., 2008).

11. N. Reisch and S. Kretzmann, A Climate of War: The War in Iraq and Global Warming (Washington, DC: Oil Change International, 2008).

12. M. A. Palmer, Guardians of the Gulf: A History of America's Expanding Role in the Persian Gulf, 1833- 1992 (New York: The Free Press, 1992).

13. Ibid., p. 107; S. A. Yetiv, Crude Awakenings: Global Oil Security and American Foreign Policy (Ithaca, NY: Cornell University Press, 2004); M. T. Klare, Blood and Oil: The Dangers and Consequences of America's Growing Dependency on Imported Petroleum (New York: Metropolitan Books, 2004).

14. K. S. Deffeyes, Hubbert's Peak: The Impending World Oil Shortage (Princeton, NJ: Princeton University Press, 2001); M. R. Simmons, Twilight in the Desert: The Coming Saudi Oil Shock and the World Economy (Hoboken, NJ: John Wiley \& Sons, Inc., 2005).

15. H. Höök, R. Hirsch, and K. Aleklett, "Giant Oil Field Decline Rates and Their Influence on World Oil Production," Energy Policy 37, no. 6 (2009): 2262-2272.

16. International Energy Agency, World Energy Outlook 2008 (Paris, France: OECD/IEA, 2008), p. 234.

17. Ibid., p. 3.

18. K. Aleklett, M.Höök, K. Jakobsson, M. Lardelli, S. Snowden, B. Söderbergh, "The Peak of the Oil Age - Analyzing the World Oil Production Reference Scenario in World Energy Outlook 2008," Energy Policy 38, no. 3 (2010): 1398-1414.

19. International Energy Agency, World Energy; U.S. Energy Information Administration, International Energy Outlook 2009, DOE/EIA0484(2009) (Washington, DC: International Energy Agency, 2009), p. 22.

20. M. Radler, "Oil, Gas Reserves Rise as Oil Output Declines," Oil \& Gas Journal 107, no. 47 (2009): 18.

21. Liska and Perrin, note 1 above.

22. Energy Information Administration, note 5 above, p. 23; International Energy Agency, note 19 above, p. 4

23. E. L. Morse, "Low and Behold: Making the Most of Cheap Oil," Foreign Affairs 88, no. 5 (2009): 36-52.

24. U.S. Congressional Research Service, The U.S. Trade Deficit, the Dollar, and the Price of Oil, RL34686 (Washington, DC: U.S. Congressional Research Service, 2008).

25. U.S. Energy Information Administration, OPEC Revenues Fact Sheet (Washington, DC: U.S. Energy Information Administration, 2009), http://www.eia.doe.gov/emeu/cabs/OPEC Revenues/pdf.pdf (accessed 11 February 2010).

26. World Bank, A Citizen's Guide to National Oil Companies: Part A, Technical Report (Washington, DC: World Bank, 2008).

27. U.S. Federal Trade Commission, note 6 above, p. 68.

28. A. Greenspan, The Age of Turbulence: Adventures in a New World (New York: The Penguin Press, 2007); U.S. Government Accountability Office, note 6 above, p. 29-36.

29. S. P. A. Brown and H. G. Huntington, Reassessing the Oil Security Premium (Washington, DC: Resources for the Future, 2010), www. rff.org (accessed 11 February 2010); L. Kilian, "The Economic Effects of Energy Price Shocks," Journal of Economic Literature 46, no. 4 (2008): 871-909.
30. D. Moran and J. A. Russell, "Introduction: The Militarization of Energy Security," in D. Moran and J. A. Russell, eds., Energy Security and Global Politics: The Militarization of Resource Management (New York: Routledge, 2008), pp. 2, 4.

31. F. Fukuyama, America at the Crossroads: Democracy, Power, and the Neoconservative Legacy (New Haven, CT: Yale University Press, 2007), p. 2; This idea is further supported by R. N. Haass, War of Necessity, War of Choice: A Memoir of Two Iraq Wars (New York: Simon \& Schuster, 2009), pp. 4-6.

32. Fukuyama, note 31 above, p. 46.

33. Fukuyama, note 31 above, p. 79; S. C. Pelletière, America's Oil Wars (Westport: Praeger Publishers, 2004), pp. 120-121; S. A. Yetiv, Explaining Foreign Policy: U.S. Decision-Making and the Persian Gulf War (Baltimore, MD: The Johns Hopkins University Press, 2004), p. 227.

34. Pelletière, note 33 above, pp. 30-32, 132-134; Yetiv, note 3133 above, pp. 221, 227; Fukuyama, note 31 above, p. 79;

35. Yetiv, note 33 above, p. 223.

36. Palmer, note 12 above; Yetiv, note 13 above.

37. Energy Information Administration, note 5 above; For potential reserve size see, A. Juhasz The Tyranny of Oil: The World's Most Powerful Industry - and What We Must Do to Stop It (New York: Harper Collins, 2008), p. 326.

38. Yetiv, note 33 above, p. 227; Moran and Russell, note 30 above, p. 3 .

39. Yetiv, note 33 above, pp. 226-227; Pelletière, note 33 above, pp. 144, 147; J. A. Russell, "Strategy, Security and War in Iraq: The United States and the Gulf in the 21st Century," in J. A. Russell, ed., Critical Issues Facing the Middle East: Security, Politics and Economics (New York: Palgrave/MacMillan, 2006), pp. 206-207.

40. The list of analysts includes the former U.S Federal Reserve Chairman (Greenspan, note 28 above), former head of U.S Central Command (Juhasz, note 37 above, p.319), former U.S. Central Intelligence Agency senior political analys for Iraq and professor at the U.S. Army War College (Pelletière, note 33 above, p. 144), professors at U.S. Naval Postgraduate School (Moran and Russell, note 30 above), and a retired colonel in the U.S. Army and professor of international relations [A. Bacevich, The Limits of Power: The End of American Exceptionalism (New York: Metropolitan Books, 2008), pp. 9-13, 58-62].

41. Greenspan, note 28 above, p. 463.

42. Haass, note 31 above, pp. 7-10.

43. Klare, note 13 above, p. 5

44. U.S. National Energy Policy Development Group, Reliable, Affordable, and Environmentally Sound Energy for America's Future (Washington, DC: U.S. National Energy Policy Development Group, 2001), pp. 8-4, 8-5.

45. Juhasz, note 37 above, p. 342.

46. M. Brander, R. Tipper, J. Woods, R. Murphy, C. Hutchison, and G. Davis, Consequential and Attributional Approaches to LCA: a Guide to Policy Makers with Specific Reference to Greenhouse Gas LCA of Biofuels (London: Econometrica Press, Imperial College, 2008).

47. U.S. National Energy Technology Laboratory, An Evaluation of the Extraction, Transport and Refining of Imported Crude Oils and the Impact on Life Cycle Greenhouse Gas Emissions, DOE/NETL2009/1362 (Washington, DC: U.S. National Energy Technology Laboratory, 2009).

48. U.S Congress, Security and Accountability For Every Port Act Of 2006, Public Law 109-347OCT. 13, 2006 (Washington, DC).

49. U.S. Government Accountability Office, note 6 above, p. 8, 13.

50. Estimated military security costs for the Mid- dle East annually are \$27-73 billion [M. A. Delucchi and J. Murphy, "U.S. Military Expenditures to Protect the Use of Persian Gulf Oil for Motor Vehicles," Energy Policy 36, no. (2008): 2253-2264], \$97 billion [A. Dancs, M. Orisich, S. Smith, The Military Cost of Securing Energy (Northampton, MA: National Priorities Project, 2008], www.nationalpriorites.org (accessed 15 February 2010); and $\$ 138$ billion [M. R. Copulos, The Hidden Costs of Imported Oil: An Update (Arlington, VA: National Defense Council Foundation, 2007], http:/ /www.ndcf.org/ [accessed 15 February 2010]); for more information see International Center for Technology Assessment, Gasoline Cost Externalities: Security and Protection Services (Washington, DC: International Center for Technology Assessment, 2005), http:// www.icta.org/doc/RPG\%20security\%20update.pdf (accessed 15 February 2010).

51. U.S. Environmental Protection Agency, Inventory of U.S. Greenhouse Gas Emissions and Sinks: 1990-2008. 430-R-10-006 (Washington, DC; 2010).

52. A. Bacevich, note 40 above, p. 173

53. Zhuang, D. Birur, U. Baldos. 2010. Land Use Changes and Consequent CO2 Emissions due to US Corn Ethanol Production: A Comprehensive Analysis. Argonne National Laboratory. http://www. transportation.anl.gov/ ; Hertel et al., note 4 above.

54. The standard deviation for the Hertel et al. estimate is 46 percent of the mean value ( $27 \mathrm{~g}$ $\mathrm{CO}_{2}$ e per MJ) based on plausible assumptions, ibid.

55. Some of this data may be known but confidential, see U.S. Government Accountability Office, note 6 above.

56. J. M. Burr and R. O. Collins, Alms for Jihad: Charity and Terrorism in the Islamic World (Cambridge, UK: Cambridge University Press, 2006).

57. J. Deutch and J. R. Schlesinger, National Security Consequences of U.S. Oil Dependency (Washington, DC: Council on Foreign Relations, 2006); Lovins et al., note 7 above.

58. J. Anselmo, "USAF Launches Major Biofuel Initiative," Aviation Week, 30 January 2009.

59. S. LeVine, The Oil and the Glory: The Pursuit of Empire and Fortune on the Caspian Sea (New York: Random House, 2007); S. LeVine and J. Bush, "Kazakh Oil: A War Of Nerves," Business Week, 22 September 2008; M. Simmons, note 13 above.

60. A. Rashid, Taliban: Militant Islam, Oil and Fundamentalism in Central Asia (New Haven, CT: Yale University Press, 2000), p. 151; J. Foster, A Pipeline Through a Troubled Land: Afghanistan, Canada, and the New Great Energy Game (Ottawa: Canadian Centre for Policy Alternatives, 2008), www. policyalternatives. ca (accessed 15 February 2010); U.S. Congress House of Representatives, Assessing Energy and Security Issues in Central Asia, Hearing Before the Committee of International Relations (Washington, DC, 25 July 2006); K. Proninska, "Energy and Security: Regional and Global Dimensions," in Stockholm International Peace Research Institute, SIPRI Yearbook 2007: Armaments, Disarmament, and International Security (Oxford: Oxford University Press, 2007), pp. 215-240.

61. U.S. Congress House of Representatives, note 60 above

62. U.S. Congressional Budget Office. Long Term Implications of the Fiscal Year 2010 Defense Budget (Washington, DC; 2010).

63. Belasco, Amy. The Cost of Iraq, Afghanistan, and Other Global War on Terror Operations Since 9/11. U.S. Congressional Research Service RL33110 (Washington, DC; 2009). 